\title{
Are power-line corridors an alternative habitat for carabid beetle (Coleoptera: Carabidae) and wolf spider (Araneae: Lycosidae) heathland specialists?
}

\author{
Mattias Lindholm ${ }^{1}\left[\right.$ [ $\cdot$ Bengt Gunnarsson ${ }^{1} \cdot$ Thomas Appelqvist $^{1}$
}

Received: 20 September 2018 / Accepted: 25 February 2019 / Published online: 5 March 2019

(c) Springer Nature Switzerland AG 2019

\begin{abstract}
Semi-natural habitats such as heathlands, are important for the conservation of biodiversity. Due to a significant decline in traditional management, e.g. burning and grazing, in combination with habitat loss, these ecosystems have become highly threatened. On the other hand, human activities create modern infrastructures, e.g. power-line corridors (PLCs), and they can function as an alternative habitat for species for which their semi-natural habitat has degraded. This study compared the species richness and species composition of carabid beetles and wolf spiders in PLCs, traditionally managed heathlands and former heathlands that are covered with coniferous forests. We also measured vegetation variables and used it to compare species richness of plant, abundances of species and Ellenberg indicator values in the different habitats. The results showed that species richness of carabid beetles in the traditionally managed heathland is significantly higher compared to the PLCs. The species composition of carabid beetles and wolf spiders were also significantly different in these two habitats, but there was no difference between the species composition of carabid beetles and wolf spiders in the PLCs and forests. This might be explained by the similar vegetation structure in the PLCs and the forests, such as the high abundance of trees and shrubs and low abundance of typical heathland plants. Our results showed that PLCs are not an alternative habitat for the carabid beetle and wolf spider heathland specialists. We discussed how the management could be changed in the PLCs in order to make them more valuable for these and other heathland species.
\end{abstract}

Keywords Heathland $\cdot$ Carabidae $\cdot$ Lycosidae $\cdot$ Power-line $\cdot$ Species composition $\cdot$ Species richness

\section{Introduction}

The Atlantic heathlands are semi-natural ecosystems on nutrient poor and acidic soils, that have been maintained by traditional management including grazing by domestic animals, burning, and cutting (Gimingham 1972; Webb 1998; Gorissen 2004). They have been present in Europe during the whole of the Holocene period, although their extent is clearly associated with climatic shifts and human settlement

Electronic supplementary material The online version of this article (https://doi.org/10.1007/s10841-019-00141-1) contains supplementary material, which is available to authorized users.

Mattias Lindholm

mattias.lindholm@bioenv.gu.se

1 Department of Biological and Environmental Sciences, University of Gothenburg, Box 461, 40530 Gothenburg, Sweden
(Fagúndez 2013). But, since the beginning of the twentieth century, heathlands have declined in extent and quality, and among the main reasons contributing to this decline, is a significant decline in traditional management practices, such as burning and grazing (Webb 1998; Bernes 2011). As a result of these losses, the Atlantic heathland is a threatened habitat and listed in Annex I of the European Habitat Directive (COUNCIL DIRECTIVE 92/43/EEC).

Development of modern infrastructure has created environments that may provide alternative habitat for open habitat species for which the natural habitats have been largely degraded, e.g. road verges that are important for bees and wasps (Heneberg and Řezáč 2017), sandpits that are important for spiders (Heneberg and Řezáč 2014), and as in this study power-line corridors (PLCs). PLCs are kept open by regular clearing of young trees and the management creates conditions and habitats similar to extensively managed grasslands and heathlands (Grusell and Miliander 2011; Norkvist 2008). The total length of power-lines in Sweden 
is $450,000 \mathrm{~km}$, covering an area of 300,000 ha (Grusell and Miliander 2004), and this can be put in the context of the total area of 500,000 ha of semi natural grasslands in Sweden (Jordbruksverket 2008). The PLCs have therefore gained a lot of conservation interest in recent years (Berg et al. 2011, 2016). Some studies have suggested that PLCs serve as habitats for a variety of species, e.g. flower-visiting insects, reptiles and birds (Sheridan et al. 1997; Yahner et al. 2001; Russel et al. 2005; Sjödin et al. 2008; Berg et al. 2011, 2013, 2016). Other studies have shown that PLCs have a limited value for ground beetles associated with mires (Hollmen et al. 2008). No detailed study has, to our knowledge, been performed in Calluna heathland habitats in PLCs concerning the conservation value for ground-living beetles and spiders. The arthropod fauna in the Calluna heathlands are specialised, including many rare and threatened species (Desender and Turin 1989; Uscher 1992; Ljungberg 2002; Buscholz et al. 2013). Both ground-living beetles and spiders in the heathlands have strong habitat preferences, and the species composition varies according to habitat type and vegetation structure (Hopkins and Webb 1984; Usher 1992; Hsieh et al. 2002; Barriga et al. 2010; Dennis et al. 2015). They are also sensitive to the management intensity (Downie et al. 1999; Rainio and Niemelä 2003; Cuesta et al. 2006; Tyler 2008; Garcia et al. 2009; Schirmel and Buchholz 2011; Bargmann et al. 2015) and they can be used as target groups when monitoring the influence of management practices on biodiversity (Cole et al. 2005).

In the manual for managing habitats with high conservation values in PLCs in Sweden, the recommendation is that heathland habitats can be managed with only regularly clearings of trees and shrubs (Grusell and Miliander 2011). The aim of the recommendation is mainly to preserve typical heathland vegetation. But many heathland plants, e.g. Calluna vulgaris, Erica tetralix, Vaccinium vitis-idaea, V. myrtillus, Carex pilulifera, Arnica montana and Potentilla erecta, are long-lived and can persist for many years, even with less intensive management (Ekstam and Forshed 1992). However, we suspect that many ground-living heathland arthropods, i.e. carabid beetles and wolf spiders, need more intensive management and that PLCs are suboptimal habitat for these taxa.

The aim of this study was to compare Calluna heathland habitats in PLCs with traditionally-managed habitats. We included former heathlands that are now covered with coniferous forests as a third study habitat, since no management to preserve heathlands has been performed in that habitat. Our hypothesis was that the differences in management in PLCs and traditional heathlands cause differences in species composition and diversity of carabid beetles (Coleoptera: Carabidae) and wolf spiders (Araneae: Lycosidae). Carabid beetles and wolf spiders are, with a few exceptions, predators that hunt by running at ground level and most of their species would prefer open and sunny habitats (Almquist 2005; Roberts 2001). Therefore, we would expect to measure higher species richness and a different species composition in the traditionally managed heathland compared to the heathland habitats in the PLCs. In addition, we compared vegetation and species richness of plants at different sampling levels (point species richness, site species richness). Less disturbance in the PLCs favours competitive plants, e.g. many dwarf shrubs, at the expanse of ruderals, e.g. many annual herbs (Grime 2002), and we expected to have higher species richness of plants in the traditionally managed heathlands compared to the heathland habitats in the PLCs.

\section{Methods}

\section{Study sites}

This study took place in five locations: Remmene, Tånga hed, Sandsjöbacka, Näsbokrok and Mästocka, all of which are in south-west Sweden (Fig. 1). The smallest distance between two locations were $8100 \mathrm{~m}$ (Remmene vs Tånga hed). For each location, we studied three sites $(30 \times 100 \mathrm{~m})$ : (1) traditionally managed heathland, (2) heathland habitats in PLCs and (3) former heathlands, covered with 60-80year old coniferous forest. The mean distance between the heathlands and the forests was $3700 \mathrm{~m}$, between heathlands and the PLCs 3690 meters and the PLCs and the forests 484 meters. The PLCs and the heathlands were all surrounded by coniferous forests. All sites are in areas that historically have been used as heathlands. For the past 50 years, the sites with traditionally managed heathlands are burned every 10-15 years and/or grazed during the summer months. The heathlands had almost no cover of trees and tall shrubs and the vegetation in the heathlands were dominated by typical heathland plants, and the ten most frequent plant species in the heathlands were: Calluna vulgaris, Deschampsia flexuosa, Potentilla erecta, Festuca ovina, Carex pilulifera, Agrostis capillaris, Vaccinium vitis-idaea, V. myrtillus, Agrostis canina and Succisa pratensis. The power-lines in Remmene, Tånga hed and Mästocka were built in the 1950s, Sandsjöbacka in the 1960s and Näsbokrok in the beginning of the 1970s. The PLCs have been kept open by regular clearing of young trees every $6-9$ years. There was a trail in the middle of the PLCs that was cut more regularly and had lower vegetation. These trails are used to inspect the power-lines. About 50\% of the area in the PLCs were covered by small trees and tall shrubs and the vegetation in the PLCs were mostly dominated by typical heathland plants, and the ten most frequent plant species in the PLCs were: Deschampsia flexuosa, Vaccinium vitis-idaea, Calluna vulgaris, Vaccinium myrtillus, Trientalis europea, Molinia caerula, Rubus subg. Rubus, R. idaeus, Potentilla erecta and 
Fig. 1 Study area in south-west Sweden with the five locations: (1) Remmene, (2) Tånga hed, (3) Sandsjöbacka, (4) Näsbokrok, (5) Mästocka

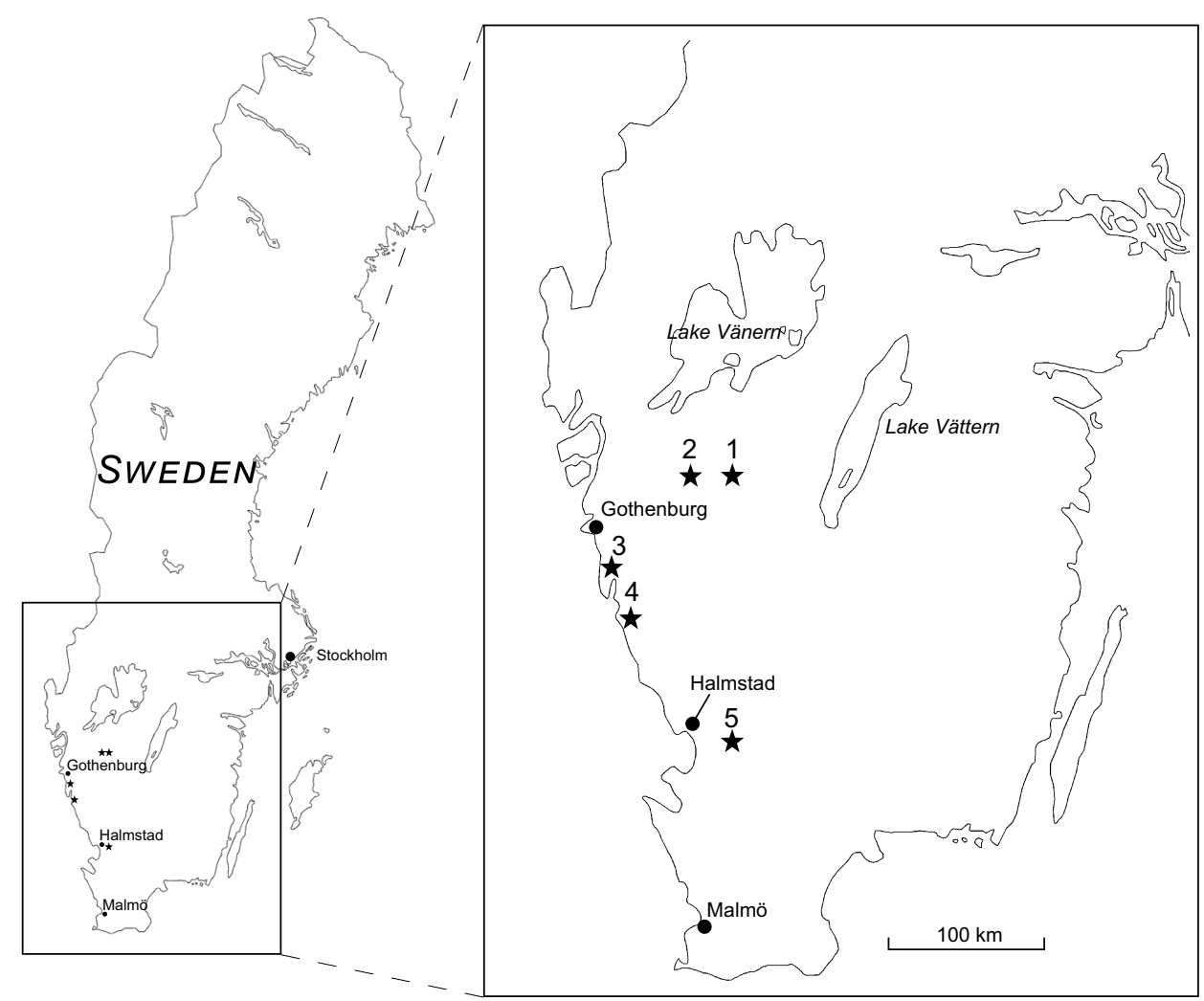

Agrostis capillaris. The forests have only been undertaken an early thinning. The ten most frequent plant species in the forests were: Vaccinium myrtillus, Deschampsia flexuosa, Vaccinium vitis-idaea, Molinia caerula, Deschampsia cespitosa, Trientalis europea, Juniperus communis, Calluna vulgaris, Maianthemum bifolium and Vaccinium uliginosum.

\section{Vegetation and environmental variables}

The sampling of vegetation and collection of environmental data was carried out in July 2014. At each site, four parallel transects ( $100 \mathrm{~m}$ long) were laid out across the site to be surveyed. The distance between the transects was 6 $\mathrm{m}$ and the samples were taken from every seventh meter along the transects. In total, fifty sampling units per site were placed along the transects, and the measurements were subsequently averaged.

The abundance of trees and shrubs ( $>1 \mathrm{~m}$ ), dwarf shrubs, herbs and mosses was estimated using a frame covering $0.25 \mathrm{~m}^{2}(0.5 \mathrm{~m} \times 0.5 \mathrm{~m})$, and the presence of each species was recorded. We also measured the frequency of each plant species in the sample units by dividing the frame into nine quadrats with strings. The presence of each species was recorded and a value of 1-9 obtained. These values were then used to get environmental factors using the Ellenberg indicator values adapted from Ellenberg et al. (1992). Ellenberg indicator values are widely used by plant ecologist in both central and north Europe (e.g. Persson 1980; Diekmann 1994; Thompson et al. 1993; Hill et al. 1999). They are based on ecological observations and were originally derived for use in Central Europe, but they are also suitable for use in northern Europe (Thompson et al. 1993). Previous studies have shown that Ellenberg indicator values correlated significantly with the results of empirical experiments (Thompson et al. 1993; Shaffers and; Sýkora 2000). The variables in this study follow the coding system: nitrogen $(\mathrm{N})$, moisture $(\mathrm{F})$, light $(\mathrm{L})$ and reaction $(\mathrm{R})$. Reaction $(\mathrm{R})$ stands for the acidity of the soil and can be comparable with $\mathrm{pH}$. The Ellenberg indicator values temperature $(\mathrm{T})$ and continentality $(\mathrm{K})$ have been omitted since they do not correspond well in this region (Hill et al. 1999). A more detailed explanation of the variables can be found in Ellenberg et al. (1992). To estimate the composite value of an environmental variable for each sampling unit, the weighted average was calculated according to the equation in Diekmann (2003):

$W A_{j}=\frac{\sum_{i=1}^{n}\left(r_{i j} \times x_{i}\right)}{\sum_{i=1}^{n} r_{i j}}$

$\mathrm{WA}_{j}$ is the weighted average for sampling unit $j, \mathrm{r}_{\mathrm{ij}}$ are the response of species $i$ in sample unit $j$, and $x_{i}$ the indicator value of species $i$. Absent species and those 
lacking indicator values are disregarded. The means of the weighted averages for each site were compared.

\section{Carabid beetles and wolf spiders}

Five pitfall traps were installed at each site. Since there often was a trail in the middle of the PLCs, we choose to have the location for each trap randomly selected, but with a minimum distance of $5 \mathrm{~m}$ between the next trap and to the boundaries. Randomized sampling techniques are also preferred by Magurran (2004). The mean distance from the traps to the nearest boundaries was $17.2 \mathrm{~m}$. The pitfall traps consisted of $80 \mathrm{~mm}$ diameter, $120 \mathrm{~mm}$ deep plastic cups, filled up to one-third, with monopropylene glycol and a few drops of detergent. Each trap was covered with a roof that was fixed to the soil by four iron pegs to protect it from rain and to prevent animals from pulling out the traps. The traps were set in late April 2014 and samples were collected three times, early May, mid July and late August. The beetles and spiders were stored in $70 \%$ ethanol. Adult individuals of carabid beetles and wolf spiders were identified to species level. Since carabid beetles and wolf spiders are mobile and the sites were small with short distances between the traps, traps within each site were not replicates. Hence, data from all five traps at each site were pooled.

\section{Statistical analyses}

Vegetation and environmental variables among the three habitats were compared using one-way ANOVA and the Tukey-test as a post-hoc test. We applied Shapiro-Wilk and Levene's test to check for normal distribution of data and homogeneity of variance. Statistical differences among habitat types in abundances of six common species were tested. Three of the most common dwarf shrubs and three of the most common herbs in our data set were included in the tests. We had this limitation of three species of each group, since the statistical power decrease with more species tested. All trees and shrubs with a height over $1 \mathrm{~m}$ were tested as one group, and all mosses as another group. The analyses were carried out using the software IBM SPSS Statistics, version 24.

Following Gray (2000); we measured species richness using different scales. Point species richness is the number of species from a single sample unit. In our study, point species richness is the mean number of plant species in the field layer from one quadrat frame at one site. We only measured point species richness of the plants, since the pitfall traps were pooled at each site. Statistical differences among habitat types in point species richness were tested with one-way ANOVA. We used Shapiro-Wilk test to check for normal distribution and Levene's test for the homogeneity of variances. The data were log-transformed if necessary.
Statistical differences between pairs of habitat types were tested with Tukey's post hoc test. The tests and analyses were carried out using the software IBM SPSS Statistics, version 24.

Site species richness is the number of species from a single site. Site species richness was measured for both the vegetation and the carabid beetle and wolf spider data. The carabid beetle and wolf spider data had large differences in the number of individuals between the three habitats, and we did an individual-based extrapolation from the raw data and calculated the estimated species richness. The calculations were made following the steps in Colwell et al. (2012) and with the software EstimateS 9.1.0 (Colwell 2013). The number of carabid beetles was extrapolated to 628 individuals and the number of wolf spiders to 326 individuals.

The Shannon index of the carabid beetle data and the wolf spider data was calculated as $H^{\prime}=-\sum\left(p_{i} \times \ln p_{i}\right)$, where $p$ is relative frequency of species $i$. Statistical differences among habitat types in Shannon diversity index were tested with one-way ANOVA. We used Shapiro-Wilk test to check for normal distribution and Levene's test for the homogeneity of variances. Statistical differences between pairs of habitat types were tested with Tukey's post hoc test. The tests and analyses were carried out using the software IBM SPSS Statistics, version 24.

We performed a Canonical Correspondence Analysis (CCA) to detect potential relationships between the species of carabid beetles and wolf spiders and the variable abundance of trees and shrubs. Monte Carlo permutation test (499 permutations) was applied to estimate the significance of the CCA. The ordination and permutation test were carried out using the software Canoco, version 5.

Differences and/or similarities in community structure of carabid beetles and wolf spiders between the three habitats were tested statistically using one-way analysis of similarities (ANOSIM) randomization test, a non-parametric analogue to the standard univariate 1- and 2-way ANOVA test, and Bray Curtis similarity index. ANOSIM was performed with the software PAST version 3.0.

\section{Results}

\section{Vegetation and environmental variables}

The data and analyses of vegetation structure and environmental variables are shown in Table 1 . There were no significant differences in the environmental variables nitrogen, reaction of soil value, moisture and light, between the habitats. In this respect, we consider the habitats to be the same. All habitats had low nitrogen and soil reaction value and a moisture and light value in the middle of the scale. The variances of all values were also low. There 
Table 1 Vegetation, environmental characteristics and carabid beetle and wolf spider data in the three study habitats

\begin{tabular}{|c|c|c|c|c|c|c|}
\hline & \multirow[t]{2}{*}{ Heathland H $(\mathrm{n}=5)$} & \multirow{2}{*}{$\begin{array}{l}\text { Power-line corridor } \\
\text { PLC }(n=5)\end{array}$} & \multirow[t]{2}{*}{ Forest $F(n=5)$} & \multicolumn{3}{|c|}{ Pairwise comparison } \\
\hline & & & & H-PLC & $\mathrm{H}-\mathrm{F}$ & PLC-F \\
\hline \multicolumn{7}{|l|}{ Carabid beetles } \\
\hline Individuals & $125.4 \pm 91.4$ & $18.2 \pm 6.0$ & $37.8 \pm 16.1$ & $* *$ & $*$ & ns \\
\hline Raw species richness & $10.8 \pm 3.9$ & $6.6 \pm 2.1$ & $6.0 \pm 2.1$ & ns & ns & ns \\
\hline Estimated species richness & $32.0 \pm 2.2$ & $20.1 \pm 3.6$ & $19.5 \pm 5.6$ & $*$ & ns & ns \\
\hline Shannon diversity & $1.59 \pm 0.16$ & $1.45 \pm 0.25$ & $1.24 \pm 0.23$ & ns & ns & ns \\
\hline \multicolumn{7}{|l|}{ Wolf spiders } \\
\hline Individuals & $63.2 \pm 26.5$ & $19.6 \pm 8.2$ & $13.2 \pm 14.6$ & $*$ & $*$ & ns \\
\hline Raw species richness & $4.8 \pm 1.9$ & $3.6 \pm 0.8$ & $2.8 \pm 1.7$ & ns & ns & ns \\
\hline Estimated species richness & $10.0 \pm 1.0$ & $9.0 \pm 1.8$ & $8.0 \pm 1.8$ & ns & ns & ns \\
\hline Shannon diversity & $0.99 \pm 0.43$ & $0.98 \pm 0.20$ & $0.75 \pm 0.27$ & ns & ns & ns \\
\hline \multicolumn{7}{|l|}{ Vegetation } \\
\hline \multicolumn{7}{|l|}{ Abundance } \\
\hline Tall trees and shrubs & $2.0 \pm 3.5$ & $28.2 \pm 13.8$ & $43.4 \pm 3.1$ & $* *$ & $* * *$ & ns \\
\hline Mosses & $12.2 \pm 13.6$ & $31.0 \pm 10.4$ & $37.2 \pm 9.1$ & ns & $* *$ & ns \\
\hline \multicolumn{7}{|l|}{ Dwarf shrub species } \\
\hline Calluna vulgaris & $45.0 \pm 4.9$ & $14.4 \pm 11.1$ & $2.4 \pm 3.0$ & $* * *$ & $* * *$ & ns \\
\hline Vaccinium vitis-idaea & $22.8 \pm 18.8$ & $23.4 \pm 13.2$ & $9.2 \pm 10.6$ & ns & ns & ns \\
\hline Vaccinium myrtillus & $15.4 \pm 16.4$ & $10.4 \pm 8.4$ & $22.2 \pm 6.7$ & ns & ns & ns \\
\hline \multicolumn{7}{|l|}{ Herb species } \\
\hline Deschampsia flexuosa & $27.6 \pm 10.9$ & $43.0 \pm 4.7$ & $20.0 \pm 10.1$ & ns & ns & $*$ \\
\hline Potentilla erecta & $27.0 \pm 15.0$ & $7.8 \pm 6.8$ & $0.6 \pm 0.8$ & $*$ & $* * *$ & $*$ \\
\hline Carex pilulifera & $28.8 \pm 14.2$ & $4.8 \pm 4.2$ & $1.6 \pm 1.0$ & $*$ & $* *$ & ns \\
\hline \multicolumn{7}{|l|}{ Species richness of plants } \\
\hline Point species richness & $7.6 \pm 2.3$ & $4.4 \pm 1.0$ & $1.9 \pm 0.7$ & $*$ & $* * *$ & $*$ \\
\hline Site species richness & $28.6 \pm 7.3$ & $26.8 \pm 10.1$ & $14.2 \pm 4.3$ & ns & $* * *$ & ns \\
\hline \multicolumn{7}{|l|}{ Ellenberg score } \\
\hline Nitrogen (N) & $2.19 \pm 0.07$ & $2.97 \pm 0.15$ & $2.80 \pm 0.06$ & ns & ns & ns \\
\hline Reaction (R) & $2.65 \pm 0.11$ & $2.78 \pm 0.08$ & $2.7 \pm 0.12$ & ns & ns & ns \\
\hline Moisture (F) & $5.34 \pm 0.15$ & $5.36 \pm 0.17$ & $5.56 \pm 0.04$ & ns & ns & ns \\
\hline Light (L) & $6.86 \pm 0.36$ & $6.35 \pm 0.14$ & $6.54 \pm 0.24$ & ns & $\mathrm{ns}$ & ns \\
\hline
\end{tabular}

All values are means of original data \pm standard deviation. All data, except estimated species richness data, was compared using one-way ANOVA and pairwise comparisons by Tukey-test with $* * * \mathrm{P}<0.001, * * \mathrm{P}<0.01, * \mathrm{P}<0.05$ and $n s$ not significant. Point species richness is the mean number of plant species from one quadrat frame, and site species richness is the number of species from a single site. Estimated species richness data was calculated with Estimates

were significantly more trees and shrubs in the PLCs and forests than in the heathlands, but there was no significant difference between the forest and the PLCs. Calluna vulgaris, Potentilla erecta and Carex pilulifera had significantly higher abundance in the heathlands compared to the PLCs and forests. There was also higher abundance of Deschampsia flexuosa and Potentilla erecta in the PLCs compared to the forests. The point species richness was significantly higher in the heathlands than the other two habitats, but there were also higher point species richness in the PLCs than the forests. The site species richness was significantly higher in the heathlands than in the forests, but pairwise comparison showed no differences between the heathlands and the PLCs, nor the PLCs and forests.

\section{Carabid beetles and wolf spiders}

We recorded 40 species and 907 individuals of carabid beetles, and 16 species and 480 individuals of wolf spiders (see Online Appendix). Most frequent among the carabid beetles were Poecilus versicolor (representing 34\% of the total catch), Pterostichus oblongopunctatus (12\%), Harpalus latus (11\%), Poecilus lepidus (10\%), Pterostichus niger (7\%), Pterostichus melanarius (5\%). We recorded 18 
carabid beetle species with $\leq 3$ individuals. The most frequent wolf spiders were Pardosa pullata (47\%), Pardosa palustris (13\%), Pirata uliginosus (11\%), Trochosa terricola (10\%) and Pardosa lugubris (6\%). Five species of wolf spiders were recorded with $\leq 3$ individuals.

Number of recorded individuals of carabid beetles was significantly higher in the heathlands than the PLCs and the forests, but there was no significant difference between the PLCs and the forests (Table 1). There were no significant differences in number of species between the habitats when we analysed the original data (raw species richness, Table 1). But, when we applied individual-based rarefaction and extrapolation there was a higher species richness in the intensively managed heathlands compared to the PLCs (Fig. 2a). The species richness was lowest in the forests, but the variance was high, and it was not statistical significant (Fig. 2a). The Shannon index of carabid beetles was low in all habitats and there were no significant differences between the habitats (Table 1).

Number of recorded individuals of wolf spiders was significantly higher in the heathlands than the PLCs and the forests, but there was no significant difference between the PLCs and the forests (Table 1). There were no significant differences in species richness of wolf spiders between the habitats, even after we applied individual-based rarefaction and extrapolation (Table 1; Fig. 2b). The Shannon index of wolf spiders was low in all habitats and there were no significant differences between the habitats (Table 1).

Figure 3 shows the resulting CCA diagram for the abundance values of carabid beetles and wolf spider assemblages along the gradient of trees and shrubs. The first axis (abundance of tall trees and tall shrubs) explains about $18 \%$ of the total variance in the carabid beetle and wolf spider species data. The effect of the abundance of trees and shrubs on the species composition is significant, as confirmed by the reported result of the Monte Carlo permutation test (499 permutations, $\mathrm{P}=0.002$ ). The biplot diagram shows the species that have their abundances well explained by the first ordination axis, i.e. by the abundance of trees and shrub, and ignore their fit on the second axis. The CCA detected a group of species that was clearly associated with the high abundance of trees and shrub. It consisted of the carabid beetles Agonum fuliginosum, Carabus hortensis, Carabus violaceus, Calathus micropterus, Pterostichus oblongopunctatus and the wolf spiders Pardosa lugubris, Pirata uliginosus, (Fig. 3). All these species are considered generalists in shaded habitats (Lindroth 1985, 1986; Almquist 2005). 25\% of the individuals in this group were found in the PLCs, $72 \%$ in the forests and $2 \%$ in the heathlands. The CCA also shows the species that decreased with the high abundance of trees and shrub: the carabid beetles Bembidion lampros, Calathus melanocephalus, Harpalus fuliginosus, H. latus, Pterostichus versicolor and Synuchus nivalis, and the wolf spiders Pardosa pullata and Pardosa palustris. $90 \%$ of the individuals in the group were found in the heathlands, $10 \%$ in the PLCs and no individual in the forests. The ANOSIM analysis showed statistically significant differences between both the carabid beetle communities and the wolf spider communities in the heathlands and PLCs, but there was no significant difference between PLCs and forests (Table 2). a

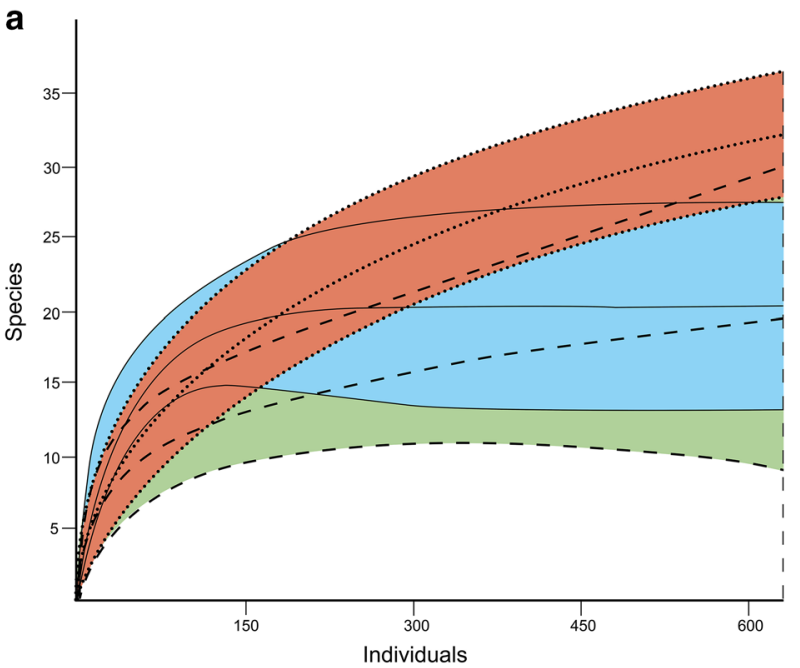

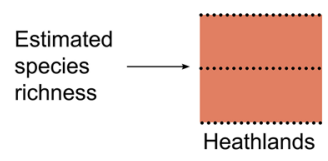

b

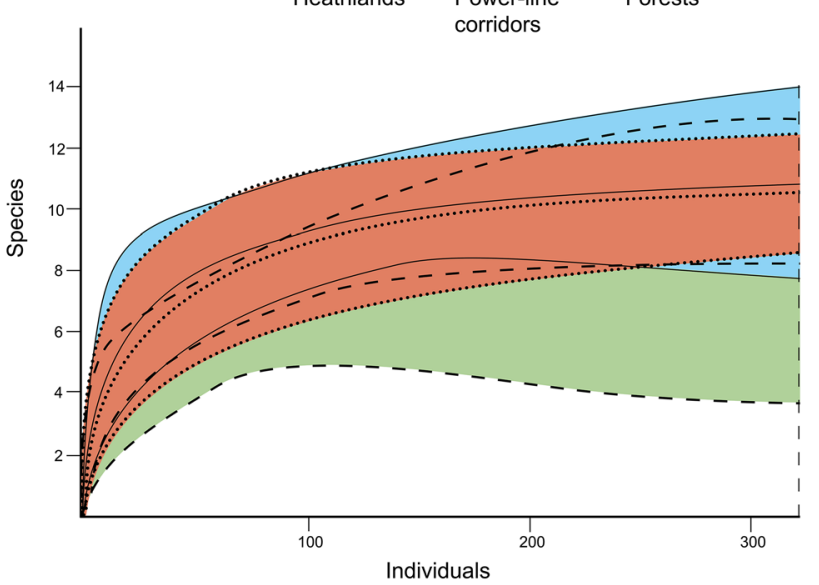

Fig. 2 Estimated number of species and 95\% confidence intervals of (a) carabid beetles and (b) wolf spiders according to extrapolation analyses 


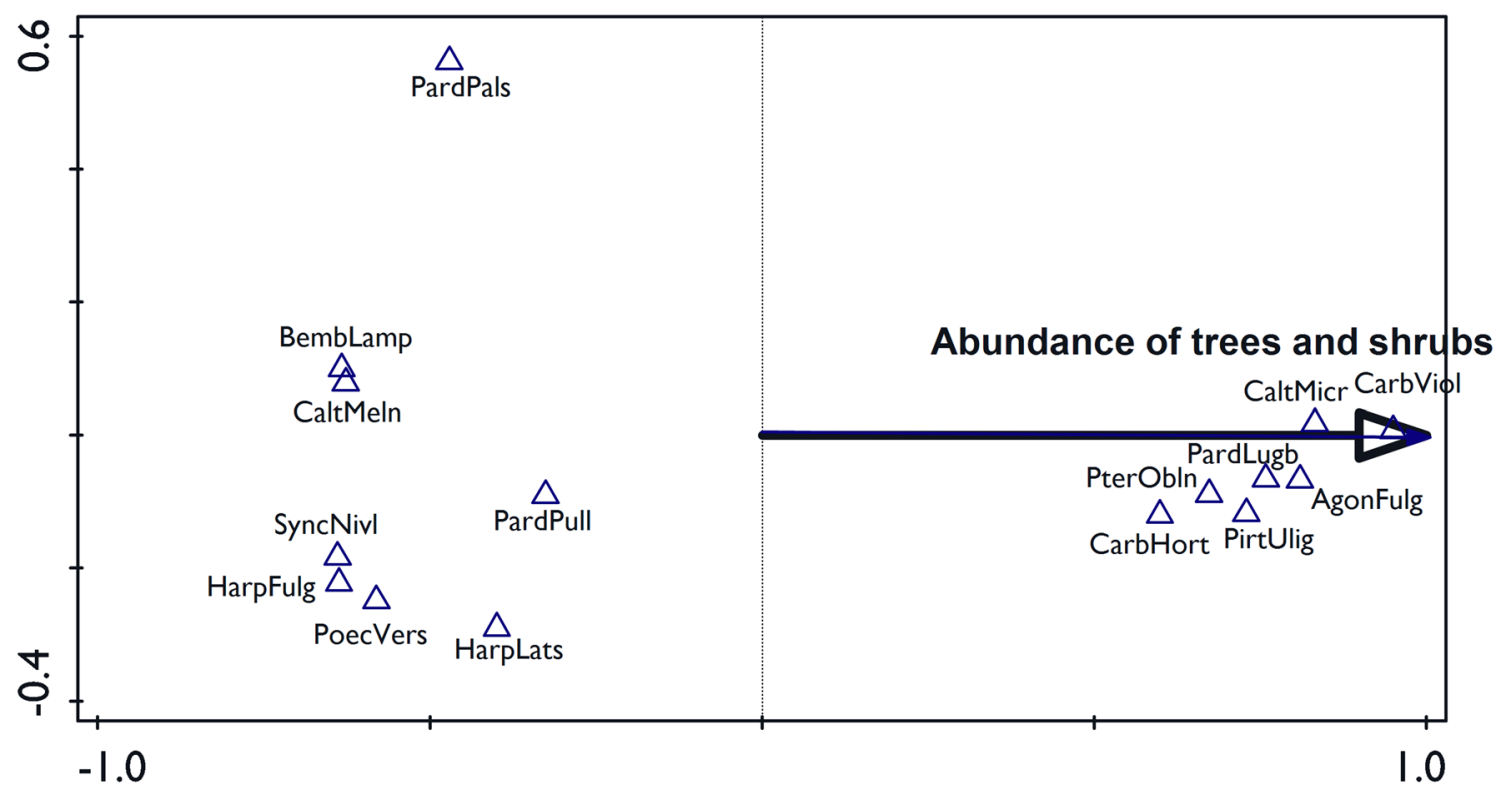

Fig. 3 Biplot diagram from CCA summarising the differences in carabid beetles and wolf spider assemblages along the gradient of trees and shrubs. Fifteen species, best fitted in the CCA by the abundance of trees and shrubs, are shown. AgonFulg=Agonum fuliginosum, BembLamp $=$ Bembidion lampros, CaltMeln =Calathus melanocephalus, $\quad$ CaltMicr $=$ Calathus micropterus, $\quad$ CarbHort $=$ Carabus

Table 2 Statistical significance of the differences in carabid beetle and wolf spider community structure (9999 permutations)

\begin{tabular}{lll}
\hline & ANOSIM & \\
\cline { 3 - 3 } & $\mathrm{R}$ & $\mathrm{P}$ \\
\hline Carabidae & & \\
Heathland vs power-line corridor & 0.524 & 0.023 \\
Heathland vs forest & 0.796 & 0.027 \\
Power-line corridor vs forest & 0.47 & 0.073 \\
Lycosidae & & \\
Heathland vs power-line corridor & 0.458 & 0.047 \\
Heathland vs forest & 0.796 & 0.019 \\
Power-line corridor vs forest & 0.078 & 0.938 \\
\hline
\end{tabular}

The ANOSIM statistic $\mathrm{R}$ is based on the difference of mean ranks between groups. Large R signifies dissimilarity between groups. Significant comparisons at $\mathrm{P}<0.05$

\section{Discussion}

The vegetation in the PLCs contained heathland species that were not different from the species in the managed heathlands in respect of nitrogen, moisture, reaction (acidity or $\mathrm{pH}$ ) and light, according to the Ellenberg indicator values. The PLCs were also quite open and about half of the area in the PLCs were not covered with trees or tall hortensis, $\quad$ CarbViol=Carabus violaceus, HarpFulg = Harpalus fuliginosum, HarpLats = Harpalus latus, PardLugb=Pardosa lugubris, PardPals=Pardosa palustris, PardPull=Pardosa pullata, PirtUlig = Pirata uliginosus, PoecVers $=$ Poecilus versicolor, PterObln = Pterostichus oblongopunctatus, SyncNivl = Synuchus nivalis

shrubs. The PLCs in our study can therefore be classified as heathland habitats (Elkington et al. 2001). But, they might correspond to either a mature or degenerate phase (see Giminingham 1972), i.e. the vegetation is old and dense and the Calluna has started to die. Our data showed less abundance of Calluna vulgaris in the PLCs compare to the heathlands, and less abundance of the typical heathland species Potentilla erecta and Carex pilulifera. We could also detect a lower point species richness of plants in the PLCs, which is typical when there is less disturbance and competitive species became more dominant (Grime 2002). But, there were no differences in site species richness of plants between the PLCs and the heathlands. It can be explained by the fact that there was a trail in the middle of the PLCs that were more intensively managed, and these trails are probably suitable for ruderals. So, even if the PLCs and the heathlands have some similarities, the differences in the vegetation between these habitats have an effect on the carabid beetle and wolf spider fauna. The species composition of carabid beetles and wolf spiders in the PLCs was significantly different from the traditionally managed heathlands, but the species composition in the PLCs did not differ from the forests. The cutting of trees and tall shrubs every 6-9 years in the PLCs is probably not enough to create large areas with well managed heathland vegetation. There are instead old successional stages in the PLCs, with high and dense vegetation that 
favours shade tolerant forest species. We could show this in our CCA that had two well separated groups of species according to the abundance of trees and shrubs. This result is consistent with other studies that show that shading and moisture are the most important environmental factors explaining the distribution of carabid beetles and spiders (Uscher 1992; Buschholz 2010). The lower abundance of Calluna vulgaris in the PLCs may also have an effect on the fauna. Calluna vulgaris is often regarded as a keystone species for heathland invertebrate fauna, including carabid beetles and spiders (Littlewood et al. 2006; Schirmel and Buchholz 2011). Calluna supports a significant arthropod fauna and some invertebrates feed directly on the plant, others are predators of Calluna feeders, e.g. many carabid beetles and wolf spiders. Many more use Calluna merely as an architectural feature (Kirby 2013). Some species may therefore be missing in the PLCs that have less of Calluna. The shape of the PLCs may also have an effect of the species composition of carabid beetles and wolf spiders. The PLCs are quite narrow and surrounded by coniferous forests. Forest species, e.g. Agonum fuliginosum and Pterostichus oblongopunctatus, may therefore disperse easily into the PLCs, even by chance. We tried to minimize this edge effect by having power-lines with wide corridors ( $>40 \mathrm{~m}$ ) and not having the traps closer to the edges than $5 \mathrm{~m}$.

The PLCs had significantly lower species richness of carabid beetles than the traditionally managed heathlands. This might also be explained by the differences in the vegetation structures. Other studies have shown that early successional stages have more species of carabid beetles and spiders than late successional stages (Schirmel and Buchholz 2011; Bargman et al. 2015). The number of species in the PLCs might also be affected by fragmentation. Many carabid beetles are thought not to disperse more than a few $100 \mathrm{~m}$ in 1 year (Klazenga and de Vries 1994; Vermulen 1994), and if the PLCs are well isolated it will take a long time before they get a diverse heathland fauna. We tried to reduce these differences among the sites by having PLC and forest sites that were close to traditionally managed heathlands, and by choosing PLCs that were at least 45 years old. This should probably have allowed enough time for the heathland species to colonise the PLCs.

We did not find the same differences in species richness between the habitats of wolf spiders as with carabid beetles, but our sample of wolf spiders was quite small, only 480 individuals, and this may have been too few for the analyses. Schirmel and Buchholz (2011) analysed a larger data set and they found more spider species and indicator species in the youngest stage of heathland succession. Spiders are known for having good dispersal abilities and the instars are using ballooning to move long distances (Duffey 1998; Richter 1970). They are probably less affected by fragmentation than carabid beetles. This may also be a part of the explanation why we did not observed differences in species richness between the PLCs and the heathlands.

The Shannon index of carabid beetles and wolf spiders was low in all habitats, probably due to low species richness and that there were a relatively small number of species that were more numerous. We could suspect a trend that the Shannon index seemed to be higher in the more opened habitats.

It is interesting that we recorded almost seven times more individuals of carabid beetles and three times more individuals of wolf spiders in the heathlands than the PLCs. This indicates that we had a higher activity of carabid beetles and wolf spiders in the more open habitats. Many carabid beetles and the wolf spiders are xerothermic and they prefer to live in hot and dry conditions. The intensive managed heathlands are probably a better environment for those species than the PLCs that have high and dense vegetation and humid and cold microclimate conditions (Kirby 2013; Delany 1953).

Ljungberg (2001) listed indicator carabid beetles for heathlands and semi-natural grasslands in Sweden. According to this list, we had six indicator species in the sites with traditionally managed heathland, and only one in the PLCs and the forests (Online Appendix). This supports the idea that the PLCs are not optimal habitats for these xerothermic species. Our study was not designed to capture or have focus on threatened species, but we found one species that is listed on the Swedish Red List (Artdatabanken 2015): the carabid beetle Poecilus punctulatus EN (endangered), that was captured in a traditionally managed heathland. Almost all heathland carabid beetles and wolf spiders that are threatened prefer heathlands with vegetation in an early successional stage (Lindroth 1985, 1986; Almquist 2005; Artdatabanken 2015).

\section{Conclusion and implications for conservation}

In conclusion, our study shows that the PLCs and the traditionally managed heathlands have clear differences in the carabid beetles and wolf spider heathland fauna that they house. This is probably an effect of the extensive management of the PLCs. Therefore, we conclude that the current management in the PLCs results in a low conservation value as an alternative habitat for carabid beetle and wolf spider heathland specialists.

Our study verified the importance of young successional stages for the typical heathland fauna. Based on these results, it is possible to give some advice for successful habitat management of the PLCs focusing on arthropod conservation. Firstly, there should be more open habitats in the early successional stages, with sparse and low vegetation. This is considered most important for rare carabid beetles and ground 
living spiders (Ljungberg 2002; Buchholtz 2010; Schirmel and Buchholz 2011). More frequent clearing of vegetation, combined with mowing of the PLCs are also suggested for butterfly conservation (Kommonen et al.2013; Berg et al. 2013, 2016). Fire is an is an important management strategy for the conservation of European heathlands, as it maintains an open landscape, and has an impact on the diversity and composition of the fauna and flora (Mallik and Gimingham 1983; Usher 1992; Uscher and Thompson 1993; Bargmann et al. 2015). But, fires might cause damage to the lines and the insulators and there is also a risk that the line is short circuited due to soot particles, and should be avoided as a management treatment in the PLCs (Svenska 2019). Secondly, there should still be a balance between different successional stages, from early to late, in the PLCs, to ensure that the ecological needs of several species groups are met, not only for ground living arthropods but also for birds, bees, butterflies and other groups that use different ecological niches in the heathlands.

Acknowledgements We would like to thank Västkuststiftelsen and the County administrations of Halland and Västra Götaland for permission to conduct this study in Mästocka, Tånga hed, Sandsjöbacka and Näsbokrok. Furthermore, our thanks go to Vikki Forbes and two anonymous reviewers who provided helpful comments on the manuscript.

Funding This study was funded by Erik \& Lily Philipsons minnesfond.

\section{Compliance with ethical standards}

Conflict of interest The authors declare that they have no conflict of interest.

Open Access This article is distributed under the terms of the Creative Commons Attribution 4.0 International License (http://creativeco mmons.org/licenses/by/4.0/), which permits unrestricted use, distribution, and reproduction in any medium, provided you give appropriate credit to the original author(s) and the source, provide a link to the Creative Commons license, and indicate if changes were made.

\section{References}

Almquist S (2005) Swedish Araneae, part 1, families Atypidae to Hahniidae. Insect Syst Evol Suppl 62:1-284

Artdatabanken (2015) Rödlistade arter i Sverige 2015. Artdatabanken SLU, Uppsala. (In Swedish)

Bargmann T, Hatteland B, Grytnes A (2015) Effects of prescribed burning on carabid beetle diversity in coastal anthropogenic heathlands. Biodivers Conserv 24(10):2565-2581

Barriga JC, Lassaletta L, Moreno AN (2010) Ground-living assemblages from Mediterranean habitats under different management conditions. J Arachnol 38:258-269

Berg $\AA$, Ahrné K, Öckinger E, Svensson R, Söderström B (2011) Butterfly distribution and abundance is affected by variation in the Swedish forest-farmland landscape. Biol Conserv 144(12):2819-2831
Berg Å, Ahrne K, Öckinger E, Svensson R, Wissman J (2013) Butterflies in semi-natural pastures and power-line corridors-effect of flower richness, management and structural characteristics. Insect Conserv Divers 6:639-657

Berg Å, Bergman KO, Wissman J, Zmihorski M, Öckinger E (2016) Power-line corridors as source habitat for butterflies in forest landscapes. Biol Conserv 201:320-326

Bernes C (2011) Biodiversity in Sweden. Monitor 22. The Swedish Environmental Protection Agency, Stockholm

Buchholz S (2010) Ground spider assemblages as indicators for habitat structure in inlands sand ecosystems. Biodivers Conserv 19:2565-2595

Buchholz S, Hannig K, Schirmel J (2013) Losing uniqueness—shifts in carabid species composition during dry grassland and heathland succession. Anim Conserv 16(6):661-670

Clarke KR (1993) Non-parametric multivariate analysis of changes in community structure. Aust J Ecol 18:117-143

Cole L, McCracken D, Downie I, Dennis P, Foster G, Waterhouse T, Murphy K, Griffin A, Kennedy M (2005) Comparing the effects of farming practices on ground beetle (Coleoptera: Carabidae) and spider (Araneae) assemblages of Scottish farmland. Biodivers Conserv 14(2):441-460

Colwell RK (2013) EstimateS: Statistical estimation of species richness and shared species from samples. Version 9. http://purl. oclc.org/estimates

Colwell R, Chao A, Gotelli N, Lin S, Mao C, Chazdon R, Longino J (2012) Models and estimators linking individual-based and sample-based rarefaction, extrapolation and comparison of assemblages. J Plant Ecol 5(1):3-21

Cuesta D, Tabaoada A, Calvo L, Sagado J (2006) A preliminary investigation of ground beetle (Coleoptera: Carabidae) assembalges and vegetation community structure in Calluna vulgaris heathlands in NW Spain. Entomol Fenn 17:241-252

Delany M (1953) Studies on the microclimate of "Calluna" heathland. J Anim Ecol 22(2):227-239

Dennis P, Skartveit J, Kunaver A, McCracken DI (2015) The response of spider (Araneae) assemblages to structural heterogeneity and prey abundance in sub-montane vegetation modified by conservation grazing. Glob Ecol Conserv 3:715-728

Desender K, Turin H (1989) Loss of habitats and changes in the composition of the ground and tiger beetle fauna in 4 West European-countries since 1950 (Coleoptera, Carabidae, Cicindelidae). Biol Conserv 48:277-294

Diekmann M (1994) Deciduous forest vegetation in Boreonemoral Scandinavia. Acta Phytogeographica Suecica 80:1-112

Diekmann M (2003) Species indicator values as an important tool in applied plant ecology-a review. Basic Appl Ecol 4(6):493-506

Downie IS, Wilson WL, Abernethy VJ, MacCracken DI, Foster GN, Ribera I, Murphy KJ, Waterhouse A (1999) The impact of different agricultural land-uses on epigeal spider diversity in Scotland. J Insect Conserv 4:273-286

Duffey E (1998) Aerial dispersal in spiders. Proceedings of the 17th European Colloquium of Arachnology, Edinburgh 1997

Elkington T, Dayton N, Jackson DL, Strachan IM (2001) National vegetation classification: field guide to mires and heaths. Joint Nature Conservation Committee, Peterborough

Ellenberg H, Weber HE, Düll R, Wirth V, Werner W, Paulissen D (1992) Zeigerwerte von Pflanzen in Mitteleuropa. Scripta Geobotanica 18

Fagúndez J (2013) Heathlands confronting global change: drivers of biodiversity loss from past to future scenarios. Ann Bot 111(2):151-172

Garcia RR, Jauregui BM, Garcia U, Osoro K, Celaya R (2009) Effects of livestock breed and grazing pressure on ground dwelling arthropods in Cantabiran heathlands. Ecol Entomol 34:466-475 
Gimingham CH (1972) Ecology of heathlands. Chapman and Hall, London

Gimingham CH (1983) Regeneration of heathland plants following burning. Plant Ecol 53(1):45-58

Gorissen I (2004) Die Zwergstrauch-Heiden Europas - vom Atlantik bis zum Kaukaus und Ural (Dwarf shrub heaths of Europé from Atlantic to Caucasus und Ural). Verlag Ingemar Gorissen, Siegburg

Gray J (2000) The measurement of marine species diversity, with an application to the benthic fauna of the Norwegian continental shelf. J Exp Marine Bio Ecol 250(1):23-49

Grime JP (2002) Plant strategies, vegetation processes and ecosystem properties, 2nd ed. Wiley, New York

Grusell E, Miliander S (2004) Gis-baserad identifiering av artrika krafledningsgator inom stamnätet. Rapport Svenska Kraftnät nr 1960900. In Swedish

Grusell E, Miliander S (2011) Fältmanual för skötsel av kraftledningsgatans biotoper. Svenska Kraftnät, In Swedish

Heneberg B, Řezáč M (2014) Dry sandpits and gravel-sandpits serve as key refuges for endangered epigeic spiders (Araneae) and harvestmen (Opiliones) of Central European steppes aeolian sands. Ecol Eng 73:659-670

Heneberg B, Řezáč M (2017) Roadside verges can support spontaneous establishment of steppe-like habitats hosting diverse assemblages of bees and wasps (Hymenoptera: Aculeata) in an intensively cultivated central European landscape. Biodivers Conserv 26(4):843-864

Hill MO, Mountford JO, Roy DB, Bunce RGH (1999) Ellenberg's indicator values for British plants. Institute of Terrestrial Ecology, Huntingdon

Hollmen A, Välimäki P, Itämies J, Oksanen J (2008) The value of power line habitat in conservation of ground beetles (Coleoptera: Carabidae) associated with mires. J Insect Conserv 12:163-177

Hopkins PJ, Webb NR (1984) The composition of the beetle and spider faunas on fragmented heathlands. J Appl Ecol 21:935-946

Hsieh YL, Lin YS, Tso IM (2002) Ground spider diversity in the Kenting uplifted coral reef forest, Taiwan: a comparison between habitats receiving various disturbances. Biodivers Conserv 12:2173-2194

Jordbruksverket (2008) Ängs-och betesmarker - en genomgång av tillgänglig statistik. Jordbruksverket, Rapport 2008:30. Jönköping. In Swedish

Kirby P (2013) Habitat management for invertebrates: a practical handbook. Pelagic Publishing

Klazenga N, De Vries HH (1994) Walking distance of five differently sized ground beetle species. Proc Sect Exp Appl Entomol Soc 5:99-100

Kommonen A, Lensu T, Kotiaho JS (2013) Optimal timing of powerline right-of-way management for conservation of butterflies. Insect Conserv Divers 4:522-529

Lindroth CH (1985) The Carabidae (Coleoptera) of Fennoscandia Denmark. Fauna Entomologica Scandinavica, vol 15(1) E.J. Brill Scandinavian Science Press Ltd

Lindroth CH (1986) The Carabidae (Coleoptera) of Fennoscandia Denmark. Fauna Entomologica Scandinavica, vol 15(2) E.J. Brill Scandinavian Science Press Ltd

Littlewood NA, Pekman RS, Woodin SS (2006) The response of plant and insect assemblages to the loss of Calluna vulgaris from upland vegetation. Biol Conserv 128:335-345

Ljungberg H (2001) Jordlöpare som indikatorer vid övervakning av värdefulla naturmiljöer. Länsstyrelsen i Östergötland, rapport 2001:18. Linköping. In Swedish

Ljungberg H (2002) Important habitats for red-listed ground beetles in Sweden. Entomol Tidskrift 123:167-185
Magurran A (2004) Measuring biological diversity. Blackwell Publishing, Oxford

Magurran A, McGill B (eds) (2011) Biological diversity: Frontiers in measurement and assessment. Oxford University Press, New York

Norkvist K (2008) Skyddsvärda arter och biotoper i kraftledningsgator. Länsstyrelsen i Jönköpings län, rapport 2008(4). In Swedish

Påhlsson L (ed) (1998) Vegetationstyper i Norden (Tema Nord 1998:510). Nordisk Ministerråd, Köpenhamn

Persson S (1980) Succession in a South Swedish deciduous wood: a numerical approach. Vegetatio 43(1):103-122

Rainio J, Niemelä J (2003) Ground beetles (Coleoptera: Carabidae) as bioindicators. Biodiver Conserv 12:487-506

Richter C (1970) Aerial dispersal in relation to habitat in eight wolf spider species (Pardosa, Araneae, Lycosidae). Oecologia 5(3):200-214

Roberts MJ (2001) Spiders of Britain and Northern Europe. HarperCollins Publishers, New York

Russell KN, Ikerd H, Droege S (2005) The potential conservation value of unmowed powerline strips for native bees. Biol Conserv 124(1):133-148

Schaffers A, Sýkora K (2000) Reliability of Ellenberg indicator values for moisture, nitrogen and soil reaction: a comparison with field measurements. J Veg Sci 11(2):225-244

Schirmel J, Buchholz S (2011) Response of carabid beetles (Coleoptera: Carabidae) and spiders (Araneae) to coastal heathland succession. Biodivers Conserv 20:1469-1482

Sheridan PM, Orzell SL, Bridges EL (1997) Powerline easements as refugia for state rare seepage and pineland plant taxa. The Sixth International Symposium on Environmental Concern in Rights-ofWay Management (ed. by J.R. Williams, J.W. Goodrich-Mahoney and J. Wisniewski), pp 451-460. Elsevier Science, Oxford

Sjödin NE, Bengtsson J, Ekbom B (2008) The influence of grazing intensity and landscape composition on the diversity and abundance of flower-visiting insects. J Appl Ecol 45:763-772

Svenska K (2019) Safety around power lines. Retrieved 2019 January 9 from https://www.svk.se/en/national-grid/safety-around-power -lines/

Swedish Environmental Protection Agency (2018) Sweden's environmental objectives - an introduction. Bromma

Thompson K, Hodgson JG, Grime JP, Rorison IH, Band SR, Spencer RE (1993) Ellenberg numbers revisited. Phytocoenologia 23:277-289

Tyler G (2008) The ground beetle fauna (Coleoptera: Carabidae) of abandoned fields, as related to plant cover, previous management and succession stage. Biodivers Conserv 17:155-172

Uscher MB (1992) Management and diversity of arthropods in Calluna heathland. Biodivers Conserv 1(2):63-79

Uscher MB, Thompson DBA (1993) Variation in upland heathland of Great Britain: conservation importance. Biol Conserv 66(1):69-81

Vermeulen H (1994) Corridor function of a road verge for dispersal of stenotopic heathland ground beetles carabidae. Biol Conserv 69(3):339-349

Webb N (1998) The traditional management of European heathlands. J Appl Ecol 35(6):987-990

Yahner RH, Bramble WC, Byrnes RR (2001) Response of amphibian and reptile populations to vegetation maintenance of an electric transmission line right-of-way. J Arboric 27(4):215-221

Publisher's Note Springer Nature remains neutral with regard to jurisdictional claims in published maps and institutional affiliations. 